\title{
Cu(II) Benzoylpyridine Thiosemicarbazone Complexes: Inhibition of Human Topoisomerase II $\alpha$ and Activity against Breast Cancer Cells
}

\author{
Jennifer D. Conner ${ }^{1}$, Wathsala Medawala1, Madison T. Stephens ${ }^{1}$, William H. Morris ${ }^{1}$, \\ Joseph E. Deweese ${ }^{2,3}$, Patrick L. Kent ${ }^{4}$, Jeffery J. Rice ${ }^{4}$, Xiaohua Jiang ${ }^{1}{ }^{*}$, Edward C. Lisic ${ }^{*}$ \\ ${ }^{1}$ Department of Chemistry, Tennessee Technological University, Cookeville, TN, USA \\ ${ }^{2}$ Department of Pharmaceutical Sciences, Lipscomb University, Nashville, TN, USA \\ ${ }^{3}$ Department of Biochemistry, Vanderbilt University, Nashville, TN, USA \\ ${ }^{4}$ Department of Chemical Engineering, Tennessee Technological University, Cookeville, TN, USA \\ Email: "edlisic@tntech.edu,xjiang@tntech.edu
}

Received 15 March 2016; accepted 26 April 2016; published 29 April 2016

Copyright (C) 2016 by authors and Scientific Research Publishing Inc.

This work is licensed under the Creative Commons Attribution International License (CC BY).

http://creativecommons.org/licenses/by/4.0/

\section{(c) (i) Open Access}

\begin{abstract}
The focus of this research is on the study of a series of copper (II) benzoylpyridine thiosemicarbazone complexes. Of the six benzoylpyridine thiosemicarbazone ligands used in this study, two are reported for the first time; 2-benzoylpyridine tert-butyl thiosemicarbazone (BZP-tBTSC), and 2-benzoylpyridine benzyl thiosemicarbazone (BZP-BzTSC). Once characterized by NMR, melting point, and MS, these mono-anionic tridentate ligands were then reacted with $\mathrm{Cu}^{2+}$ to form the new square planar metal complexes [Cu(BZP-tBTSC)Cl] and [Cu(BZP-BzTSC)Cl]. All of the copper complexes display marked inhibition of human topoisomerase II $\alpha$. The [Cu(BZP-tBTSC)Cl] complex shows marked activity against human breast cancer cell lines.
\end{abstract}

\section{Keywords}

Topoisomerase II $\alpha$, Alpha-(N)-Heterocyclic Thiosemicarbazones, Breast Cancer Cells

\section{Introduction}

Thiosemicarbazones are an interesting class of chemical compounds that have active biological and medicinal

${ }^{*}$ Corresponding author.

How to cite this paper: Conner, J.D., et al. (2016) Cu(II) Benzoylpyridine Thiosemicarbazone Complexes: Inhibition of Human Topoisomerase II $\alpha$ and Activity against Breast Cancer Cells. Open Journal of Inorganic Chemistry, 6, 146-154.

http://dx.doi.org/10.4236/ojic.2016.62010 
qualities and have been used as drugs against leukemia [1] [2] and help cure leprosy, tuberculosis, and smallpox [3]-[5]. Additionally, these compounds also act as ligands for a wide variety of transition metals, often as high affinity multi-dentate chelating agents [1] [6] [7].

A specific subset of thiosemicarbazone ligands that have been referred to as $\alpha$-(N)-heterocyclic thiosemicarbazones have potent antiproliferative properties against a wide variety of microbes and cancer cells. Specifically, $\alpha$-(N)-heterocyclic thiosemicarbazones have been shown to have activity against ribonucleotide reductase (RNR) [8]-[10]. Further, Triapine ${ }^{\circledR}$, or 3-aminopyridine-2-carboxaldehyde thiosemicarbazone, recently entered Stage II clinical trials as an anticancer agent [11]-[13]. In addition, $\alpha$-N-heterocyclic thiosemicarbazones, with their N-N-S tridentate coordination backbone, are particularly well-known for their ability to chelate to biologically important transition metals, such as $\mathrm{Cu}(\mathrm{II})$ and $\mathrm{Fe}(\mathrm{II})$ [14]-[18].

In a fortuitous coincidence, the copper complexes of $\alpha$-(N)-heterocyclic thiosemicarbazones appear to have high antineoplastic activity through an entirely different mechanism [19]-[21]. Cu(II) acetylpyridine-thiosemicarbazone and acetylpyrazine-thiosemicarbazone metal complexes of the general formula [Cu(AP-TSC)Cl] interact with topoisomerase II $\alpha$ (topoII $\alpha$ ) [20]. Most importantly, these square-planar metal complexes appear to inhibit catalytic activity of topoII $\alpha$ [20]. The ability to catalytically inhibit topoII is significant in that this avoids the threat often presented by topoII-targeting agents. Most of the commonly-used topoII agents block ligation of cleaved DNA and are known as interfacial poisons, which result in single- and double-stranded DNA breaks [22]. This mechanism is inherently dangerous and sometimes results in therapy-related or secondary leukemias [23].

An important subset of the $\alpha$-(N)-heterocyclic thiosemicarbazones is the benzoylpyridine thiosemicarbazones (BZP-TSC's), based on 2-benzoylpyridine. One problem with the use of many of these $\alpha$-(N)-heterocyclic thiosemicarbazones as anti-cancer agents is methemoglobin formation, but one group has found that BZP-TSC ligands limit methemoglobin formation [24]. These BZP-TSC ligands have most often been employed as iron chelators because of the overabundance of iron in highly proliferative cells and because of iron's relatively low cytotoxicity [25]-[28]. Several copper (II) complexes of the benzoylpyridine thiosemicarbazone ligands have been synthesized and characterized [29]-[34], but their biological activity has not been linked to inhibition of topoII $\alpha$. This work provides that crucial link between a series of copper (II) BZP-TSC complexes and inhibition of topoII $\alpha$, as well as adding a couple of new BZP-TSC ligands and their copper(II) complexes to the literature. The structures of the BZP-TSC's and their Cu(II) complexes employed in this work are shown in Figure 1.

\section{Experimental}

\subsection{Materials and Methods}

All reagents and solvents used to synthesize the ligands and the copper complexes were purchased from SigmaAldrich or Alfa-Aesar. Recombinant human Topoisomerase II $\alpha$ was overexpressed and purified from yeast Saccharomyces cerevisiae as described [35]. The enzyme was stored in the buffer with $50 \mathrm{mM}$ Tris (pH 7.8), $750 \mathrm{mM} \mathrm{KCl}, 40 \%$ Glycerol and $0.5 \mathrm{mM}$ DTT as $1 \mathrm{mg} / \mathrm{mL}$ stock in liquid nitrogen. Recombinant pBR322
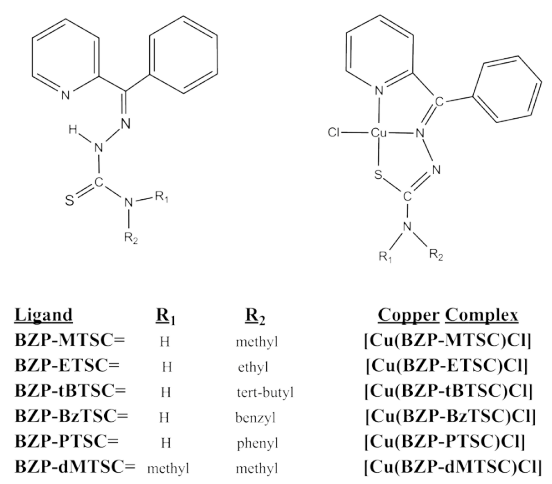

Figure 1. Structures and acronyms used for the benzoylpyridine ligands and their copper(II) complexes. 
plasmid was amplified and purified following the protocol of Qiagen ${ }^{\mathrm{TM}}$ Plasmid Mega Kit.

\subsection{Instrumentation}

The melting points were taken with a Stanford Research Systems Digimelt MPA160, and TLCs were taken with Whatman $250 \mu \mathrm{m}$ layer PE SIL G/UV polyester-backed plates. All mass spectrometry data was taken with a Varian 300/310/320-MS LC/MS Quadrupole Mass Spectrometer in negative mode using APCI. The corona current was set to $-5.00 \mu \mathrm{A}$, while the shield potential was set to -600.00 volts. The housing, drying gas, and vaporizer gas temperatures were set to $50^{\circ} \mathrm{C}, 150^{\circ} \mathrm{C}$, and $350^{\circ} \mathrm{C}$ respectively. The drying, nebulizing, and vaporizer gas pressures were each set to $12.0 \mathrm{psi}, 55.0 \mathrm{psi}$, and $17.0 \mathrm{psi}$. For the mass spectrometry data, each sample was dissolved in minimal amounts of dimethylsulfoxide and then diluted to $10 \mathrm{ppm}$ in methanol. All Nuclear Magnetic Resonance (NMR) data were collected using an Oxford/Varian $300 \mathrm{MHz}$ NMR. Each ${ }^{1} \mathrm{HNMR}$ was taken over a range of -1 to $16 \mathrm{ppm}$, with 32 - 64 total scans. The ${ }^{13} \mathrm{CNMR}$ were taken over a range of -20 to $240 \mathrm{ppm}$ and between 1000 2000 scans, with an acquisition time of 1.6s and a relaxation delay of $2.0 \mathrm{~s}$. The original data was processed in Vnmrj software, then transferred over to Mestre Nova. UV-Vis data was gathered using a Cary Varian 3E UV-Vis Spectrophotometer. Each sample was diluted to $10 \mathrm{ppm}$ and scanned over a range of 200 - $800 \mathrm{~nm}$.

\subsection{Synthesis and Characterization}

The ligands BZP-MTSC [34], BZP-ETSC [34], BZP-PTSC [32], and BZP-dMTSC [34] were synthesized by literature procedures, as well as the copper complexes [Cu(BZP-MTSC)Cl] [34], [Cu(BZP-ETSC)Cl] [34], [Cu(BZP-PTSC)Cl] [32], [Cu(BZP-dMTSC)Cl] [34], and [Cu(APY-ETSC)Cl] [20].

\subsubsection{Synthesis of BZP Ligands}

Both ligands were synthesized by the following procedure: In a $50 \mathrm{ml}$ round-bottomed 14/20 necked flask with a magnetic stir bar was added $5.50 \mathrm{mmol}$ of 2-benzoylpyridine and $5.50 \mathrm{mmol}$ of the appropriate thiosemicarbazide (either 4-tertbutyl-3-thiosemicarbazide or 4-benzyl-3-thiosemicarbazide). The reagents were slurried in 25 $\mathrm{mL}$ of 2-propanol, and one drop of concentrated sulfuric acid was added to catalyze the reaction. A reflux condensor was attached to the flask, and the reaction mixture was heated to $70^{\circ} \mathrm{C}$ and stirred for 24 hours. The offwhite precipitate formed was filtered, washed with ethyl ether, and dried under vacuum.

\section{BZP-tBTSC}

Yield: 1.53 g (89.8\%) MP: $141.5^{\circ} \mathrm{C}$

${ }^{1} \mathrm{H}$ NMR (300 MHz, DMSO-d6, $\delta$ ): 12.94 (s, 3H, hydrazinic N-H), 8.87 (ddd, J = 4.9, 0.8, $0.9 \mathrm{~Hz}, 3 \mathrm{H}, \mathrm{Ar}-\mathrm{H}$ ), 8.48 (ddd J = 4.8, 1.8, $0.9 \mathrm{~Hz}, 1 \mathrm{H}, \mathrm{Ar}-\mathrm{H}), 8.18$ (dt, J = 8.1, $1.1 \mathrm{~Hz}, 1 \mathrm{H}, \mathrm{Ar}-\mathrm{H}), 8.06$ - 7.98 (m, 5H, Ar-H), 7.91 (ddd, J = 8.1, 7.5, 1.8 Hz, 1H, Ar-H), 7.84 (s, 3H, thioamide N-H), 7.68 - 7.39 (m, 21H, Ar-H), 7.46 - 7.27 (m, 5H, Ar-H), 1.53 (s, 26H, tert-butyl C-H) ${ }^{13} \mathrm{C}$ NMR (75 MHz, DMSO-d6, $\delta$ ): 175.99 (N-C-N), 151.92 (Ar), 149.29 (Ar), 142.62 (Ar), 138.73 (tert butyl C-C-H), 137.52 (Ar), 129.76 (Ar), 129.25 (Ar), 129.07 (Ar), 126.69, 125.42 (Ar), 53.44 (tert-butyl C-H), 28.78. Anal. Found: C, 65.13; H, 6.56. Calcd. for $\mathrm{C}_{17} \mathrm{H}_{20} \mathrm{~N}_{4} \mathrm{~S}$ : C, 65.35; H, 6.45. Theoretical MS m/z (relative intensity): 311.14 (100\%). Actual MS m/z (relative intensity): 310.9 (100\%).

\section{BZP-BzTSC}

Yield: 1.57 g (82.4\%) MP: $137.2^{\circ} \mathrm{C}$

${ }^{1} \mathrm{H}$ NMR (300 MHz, DMSO-d6, $\delta$ ): 12.92 (d, J = $2.2 \mathrm{~Hz}, 1 \mathrm{H}$, hydrazinic N-H), 9.57 (t, J = $6.3 \mathrm{~Hz}, 0 \mathrm{H}$, Thioamide N-H), $9.30(\mathrm{t}, \mathrm{J}=6.3 \mathrm{~Hz}, 2 \mathrm{H}$, thioamide N-H), $8.89-8.81(\mathrm{~m}, 2 \mathrm{H}, \mathrm{Ar}-\mathrm{H}), 8.78(\mathrm{~s}, 0 \mathrm{H}, \mathrm{Ar}-\mathrm{H}), 8.52$ (dtd, J = 8.1, $1.1 \mathrm{~Hz}, 1 \mathrm{H}$, Ar-H), $8.48-8.39(\mathrm{~m}, 0 \mathrm{H}, \mathrm{Ar}-\mathrm{H}), 7.69-7.52(\mathrm{~m}, 6 \mathrm{H}, \mathrm{Ar}-\mathrm{H}), 7.58-7.36(\mathrm{~m}, 6 \mathrm{H}$, Ar-H), 7.39 - 7.15 (m, 13H, Ar-H), 4.85 (dd, J = 6.2, 2.4 Hz, 4H, benzyl N-C-H), 3.42 (d, J = 2.5 Hz, 15H, benzyl N-C-H). ${ }^{13}$ C NMR (75 MHz, DMSO-d6, $\delta$ ): 178.36 (N-C-N), 151.85 (Ar-C), 149.61 (Ar-C), 149.30 (Ar-C), 149.09 (Ar-C), 143.79 (Ar-C), 139.46 (Ar-C), 139.24 (Ar-C), 138.65 (Ar-C), 137.28 (Ar-C), 136.92 (Ar-C), 129.69 (Ar-C), 129.42 (thioamide N-C-Ar), 129.10 (Ar-C), 128.82 (Ar-C), 128.62 (Ar-C), 127.73 (Ar-C), 127.66 (Ar-C), 127.33 (Ar-C), 127.23(Ar-C), 126.57 (Ar-C), 125.38 (Ar-C), 124.47 (Ar-C), 122.17 (Ar-C), 47.73 (Ar-C). Anal. Found: C, 69.13; H, 5.56. Calcd. for $\mathrm{C}_{20} \mathrm{H}_{18} \mathrm{~N}_{4} \mathrm{~S}: \mathrm{C}, 69.34 ; \mathrm{H}, 5.24$. Theoretical MS m/z (relative intensity): 345.1 (100\%). Actual MS m/z (relative intensity): 344.9 (100\%).

\subsubsection{Synthesis of Copper Complexes}

Both $\mathrm{Cu}(\mathrm{II})$ complexes were synthesized by the following procedure: In a $50 \mathrm{ml}$ round-bottomed 14/20 necked 
flask with a magnetic stir bar was added $2.50 \mathrm{mmol}$ of cupric chloride dihydrate which was dissolved in $7.5 \mathrm{~mL}$ of methanol. Next a solution of $2.50 \mathrm{mmol}$ of the appropriate thiosemicarbazone ligand (either the BZP-tBTSC or the BZP-BzTSC) in $20 \mathrm{~mL}$ of methanol was added. Reaction to form the green product was observed to occur immediately. A reflux condenser was attached to the flask, and the reaction mixture was heated to $75^{\circ} \mathrm{C}$ and stirred for 4 hours. The green microcrystalline precipitate formed was filtered, washed with ethyl ether, and dried under vacuum.

\section{[Cu(BZP-tBTSC)Cl]}

Yield: $0.579 \mathrm{~g}(88.5 \%)$, TLC Silica/ethyl acetate $\left(\mathrm{R}_{\mathrm{f}}\right)$ : 0.91

Theoretical MS m/z (relative intensity): 413.02 (3.6\%), 412.02 (18.1\%), 411.02 (8.5\%), 410.02 (81.3\%), 409.03 (18.6\%), 408.2 (100.0\%). Actual MS m/z (relative intensity): 413.0 (19.4\%), 412.0 (17.6\%), 411.0 (82.3\%), 410.0 (30.9\%), 408.9 (100\%), 408.1 (6.9\%). Anal. Found: C, 49.55; H, 4.79. Calcd. for $\mathrm{C}_{17} \mathrm{H}_{19} \mathrm{ClCuN}_{4}$ $\mathrm{S}: \mathrm{C}, 49.75 ; \mathrm{H}, 4.67$. UV (thiosemicarbazone complexes) $\lambda_{\max }, \mathrm{nm}(\varepsilon)$ : 421 (30.85), 683 (0.6115).

\section{[Cu(BZP-BzTSC)Cl]}

Yield: $0.320 \mathrm{~g}(82.5 \%)$. TLC Silica/ethyl acetate $\left(\mathrm{R}_{\mathrm{f}}\right)$ : 0.90

Theoretical MS m/z (relative intensity): 447.01 (3.6\%), 446.00 (17.8\%), 445.01 (18.1\%), 444.01 (79.3\%), 443.01 (24.1\%), 442.01 (100.0\%). Actual MS m/z (relative intensity): 447.0 (19.7\%), 446.0 (22.2\%), 445.0 (77.3\%), 444.0 (41.6\%), 443.0 (100\%), 441.9 (12.6\%). Anal. Found: C, 53.53; H, 3.79. Calcd. for $\mathrm{C}_{20} \mathrm{H}_{17}$ $\mathrm{ClCuN}_{4} \mathrm{~S}: \mathrm{C}, 54.05 ; \mathrm{H}, 3.86$. UV (thiosemicarbazone complexes) $\lambda_{\max }, \mathrm{nm}(\varepsilon): 423$ (35.11), $684(0.6340)$.

\subsection{TopoII $\alpha$ Mediated Relaxation Assay}

Plasmid DNA relaxation assays were performed as previously described [36]. Briefly, reactions were set up in a $20 \mu \mathrm{L}$ volume with $0.5 \mu \mathrm{g}$ topoII $\alpha, 0.3 \mu \mathrm{g}$ pBR322, $2 \mathrm{mM}$ ATP in the presence of reaction buffer with $50 \mathrm{mM}$ Tris (pH7.9), $875 \mathrm{mM} \mathrm{KCl,} 0.5 \mathrm{mM}$ EDTA, $25 \mathrm{mM} \mathrm{MgCl}_{2}$ and 12.5\% glycerol. Different concentrations (10, 25, $50 \mu \mathrm{M}$ ) of TSC compounds were incubated with the above reaction mixture at $37^{\circ} \mathrm{C}$ for 30 minutes. Control reactions were performed in the presence of $10 \%$ DMSO. The reactions were then terminated with addition of 3 $\mu \mathrm{L}$ of stop solution with $77.5 \mathrm{mM}$ EDTA and $0.77 \%$ SDS. The proteins in the reaction were digested with by 2 $\mu \mathrm{L}$ of $0.8 \mathrm{mg} / \mathrm{ml}$ proteinase $\mathrm{K}$ for 30 minutes at $45^{\circ} \mathrm{C}$. The products were then mixed with $2 \mu \mathrm{L}$ of $6 \mathrm{x}$ gel loading dye from Research Products International Corp. (Mount Prospect, IL) and resolved by 1\% TBE agarose gel electrophoresis. The gels were stained in $0.5 \mu \mathrm{g} / \mathrm{ml}$ ethidium bromide and visualized by Bio-Rad Gel Doc XR+ imaging system.

\subsection{Methods for Alamar Blue Viability Assay of Cells Exposed to Topoisomerase II Inhibitors}

\subsubsection{Cell Culture and Plating}

Cell lines used were MDA-MB-231 (cancerous, epithelial-type human breast adenocarcinoma cells), and MCF7 (cancerous, epithelial-type human breast adenocarcinoma cells). Adherent cells were cultured in $25 \mathrm{~cm}^{2}$ or 75 $\mathrm{cm}^{2}$ tissue culture flasks within a humidified incubator at $37^{\circ} \mathrm{C}$ and $5 \% \mathrm{CO}_{2}$. DMEM containing L-glutamine (Lonza) supplemented with penicillin/streptomycin and 10\% FBS was used as the complete culture medium. Confluent cells were trypsinized, cell clumps dissociated by gentle pipetting, and split using a 1:10 ratio into fresh flasks containing pre-warmed complete media. Cell counts were performed by staining $100 \mu \mathrm{L}$ of cells with $100 \mu \mathrm{L}$ of trypan blue (Hyclone) and then counted on a hemocytometer. With this number determined, cells were diluted in complete media to a concentration 25,000 cells/mL, and $200 \mu \mathrm{L} / \mathrm{well}$ of a cell solutions was added to a 96-well plate using a multichannel pipette. Plated cells were placed in the humidified incubator at $37^{\circ} \mathrm{C}$ and $5 \% \mathrm{CO}_{2}$ to incubate for 24 hr prior to drug addiction.

\subsubsection{Viability Assay of the Copper Complexes}

After cells were cultured for $24 \mathrm{hr}$, after which the existing culture media was replaced with complete media containing dilutions of compounds [Cu(APY-ETSC)Cl] and [Cu(BZP-tBTSC)Cl] ranging from $100 \mu \mathrm{M}$ and $0.001 \mu \mathrm{M}$. The dilutions were generated using serial dilutions of prepared DMSO stock solutions of $10 \mathrm{mM}$ [Cu(APY-ETSC)Cl] and $10 \mathrm{mM}$ [Cu(BZP-tBTSC)Cl] in ACS-grade DMSO (Fischer) which were stored at $-20^{\circ} \mathrm{C}$ until use. Wells were also prepared with $200 \mu \mathrm{L}$ of complete media only or $200 \mu \mathrm{L}$ of complete media with 1:100 dilution of DMSO as positive controls. Both positive controls were found to be statistically equiva- 
lent showing no added toxicity of DMSO at the highest applied concentration of DMSO. The 96-well plate was then incubated (humidified, $37^{\circ} \mathrm{C}, 5 \% \mathrm{CO}_{2}$ ) for $24 \mathrm{hr}$ after application of the compounds. Alamar Blue (Thermo Scientific) was then added to each well using complete media as a carrier to attain $8 \%$ alamar blue per well and applied using a multichannel pipette. The plate was then placed back into the incubator and allowed to incubate for approximately $5 \mathrm{hr}$, after which fluorescence measurements were made at $560 \mathrm{~nm}$ excitation and $590 \mathrm{~nm}$ emission using the Tecan infinite M200 Pro reader.

\subsubsection{Data Analysis}

Initial analysis of fluorescence data were performed with Microsoft Excel 2013 normalized by the fluorescence signal from positive controls. Statistical analysis, data fitting, and plot generation was performed with GraphPad Prism 6; normalized data were fit using log (inhibitor) vs. response with variable slope (four parameter) model. This model calculated EC50 and Hill slope values for each curve.

\section{Results and Discussion}

The synthesis of the BZP-TSC ligands has been documented for over two decades, and the ligands act primarily as monoanionic tridentate chelating ligands with a variety of metal ions. Copper(II) complexes of the BZP-TSC ligands synthesized from copper (II) chloride are paramagnetic square-planar complexes in solution as has been determined previously, and we find evidence that the $[\mathrm{Cu}(\mathrm{BZP}-\mathrm{BBTSC}) \mathrm{Cl}]$ and the $[\mathrm{Cu}(\mathrm{BZP}-\mathrm{BzTSC}) \mathrm{Cl}]$ have the same solution structure. Because of the history of biological properties of the copper complexes, we decided to investigate the possibility that they are involved in inhibition of Topoisomerase II $\alpha$, just as the structurally similar acetylpyridine complexes of formula [Cu(APY-TSC)Cl] have recently been discovered to be inhibitors of that important enzyme.

\subsection{TopoII $\alpha$ Mediated Plasmid Relaxation}

The ligands and $\mathrm{Cu}(\mathrm{II})$ complexes of BZP-TSCs with different substituents were examined in a topoII $\alpha$-mediated plasmid relaxation assay. Without the presence of any compounds (ND), topoII $\alpha$ relaxed the supercoiled (SC) plasmid pBR322 to the relaxed (R) form as shown in lane 2 of Figure 2. Addition of $50 \mu \mathrm{M}$ of BZPMTSC, BZP-ETSC, BZP-tBTSC, BZP-BzTSC, BZP-PTSC or BZP-dMTSC had minor to no effect on inhibiting plasmid relaxation when compared lanes $3-8$ with lane 2 . By constrast, $50 \mu \mathrm{M}$ of $\mathrm{Cu}$ (BZP-MTSC)Cl, $\mathrm{Cu}$ (BZP-ETSC)Cl, Cu(BZP-tBTSC)Cl, Cu(BZP-BzTSC)Cl, $\mathrm{Cu}(\mathrm{BZP}-\mathrm{PTSC}) \mathrm{Cl}$ or $\mathrm{Cu}$ (BZP-dMTSC)Cl significantly inhibits topoII $\alpha$-mediated relaxation of supercoiled DNA as indicated in lanes $9-14$. Our data show that the BZP-TSC ligand has little effect on topoII $\alpha$ activity while $\mathrm{Cu}$ (BZP-TSC)Cl with different substituents all showed inhibitory effect on topoII $\alpha$, which is consistent with our studies of other TSC complexes [36].

We also examined the dose-dependence of [Cu(BZP-tBTSC)Cl] inhibition on topoII $\alpha$ as shown in Figure 3. Lane 1 shows supercoiled plasmid DNA, and Lane 6 shows topoII $\alpha$-mediated relaxed plasmid DNA. Lanes 2 -

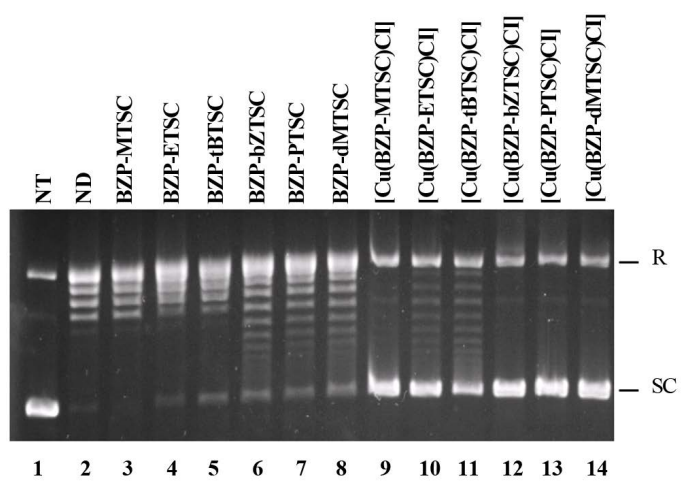

Figure 2. Copper(II) BZP-TSC complexes inhibit the plasmid relaxation mediated by human topoII $\alpha$. Lane 1 , reaction without topoII $\alpha$ (NT). Lane 2, reaction without compounds but with $10 \%$ DMSO (ND). Lanes 3 - 8. BZP-TSC ligands with methyl, ethyl, tert-butyl, benzyl, phenyl and dimethyl substituents inhibits topoII $\alpha$ slightly at a concentration of $50 \mu \mathrm{M}$. Lanes $9-14$, [Cu(BZP-TSC)Cl] with methyl, ethyl, tert-butyl, benzyl, phenyl and dimethyl substitutions inhibits topoII $\alpha$ at a concentration of $50 \mu \mathrm{M}$. 


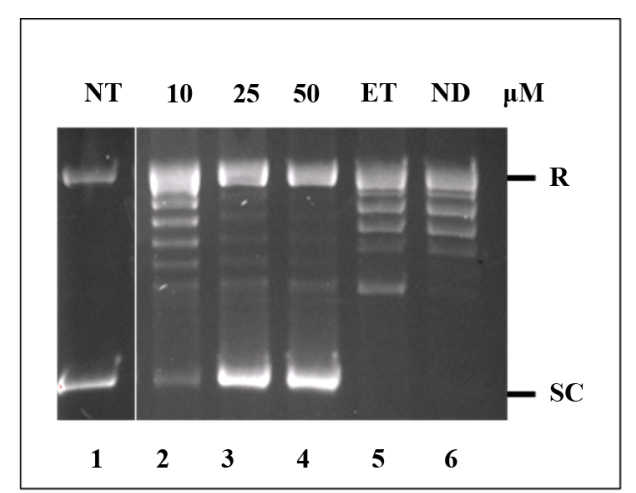

Figure 3. [Cu(BZP-tBSC)Cl] inhibit the topoII $\alpha$-mediated plasmid relaxation in a dose-dependent manner. Lane $1, \mathrm{NT}$, control reaction without topoII $\alpha$. Lanes 2 - 3, [Cu(BZP-tBSC)Cl] inhibits TopoII $\alpha$ mediated plasmid relaxation at a concentration of 10,25 , and $50 \mu \mathrm{M}$. Lane 5, etoposide weakly inhibits topoII $\alpha$-mediated plasmid relaxation at a concentration of $50 \mu \mathrm{M}$. Lane 6 , ND, control reactions without TSC's.

4 show inhibition of the topoII $\alpha$ enzyme in a dose dependent manner from $10 \mu \mathrm{M}$ solution of [Cu(BZP-tBTSC) $\mathrm{Cl}$ ] up to a $50 \mu \mathrm{M}$ solution. Our experiment shows that as little as $10 \mu \mathrm{M}$ of [Cu(BZP-tBTSC)Cl] can partially inhibit topoII $\alpha$ activity and that even at this concentration it exhibits more inhibition than does etoposide at a 50 $\mu \mathrm{M}$ solution concentration as seen in Lane 5. It should be noted that etoposide is a widely-used anticancer agent.

\subsection{In Vitro Viability Assays}

The in vitro viability assay of compounds [Cu(APY-ETSC)Cl)] and [Cu(BZP-tBTSC)Cl] was determined using two cancerous, epithelial-type human breast adenocarcinoma cell lines, MDA-MB-231 and MCF7. Compound concentrations ranging from $0.001-100 \mu \mathrm{M}$ were used and cell viability were assayed after 24 hours of incubation with the compounds in complete DMEM media. The fluorometric, metabolic compound Alamar Blue was used to determine cellular viability. As shown in Figure 4, the effective concentrations causing $50 \%$ cell death (EC50) for MDA-MB-231 cells with [Cu(APY-ETSC)Cl] and [Cu(BZP-tBTSC)Cl] is $3.33 \mu \mathrm{M}$ and $1.01 \mu \mathrm{M}$ respectively.

In all cases, the viability of the cells decreased with increasing concentration of the compounds. Compound [Cu(APY-ETSC)Cl] generally had a lower effective concentration compared to [Cu(BZP-tBTSC)Cl], but the differences were not determined to be statistically significant in these assays. The MDA-MB-231 cells had an abrupt change in viability after a certain threshold concentration of applied compounds, perhaps due to the physiology of these cells. GraphPad Prism was used to calculate the (EC50) for the various cell types.

As shown in Figure 5, the EC50 for MCF7 cells with [Cu(APY-ETSC)Cl] and [Cu(BZP-tBTSC)Cl] is 0.0558 $\mu \mathrm{M}$ and $0.248 \mu \mathrm{M}$ respectively. Previously reported viability data for [Cu(APY-ETSC)Cl] with MCF7 indicated higher EC50 values [20], but this difference is most likely due to the lower cellular concentration used in our assays. Approximately 5000 cells per well were used in these assays to allow for expansion of the cells in the 96 well plate format, as opposed to 50,000 cells per well, which would cause over confluent conditions in our assay.

\section{Conclusions}

Thiosemicarbazones that are of the $\alpha$-(N)-heterocyclic thiosemicarbazone class, such as the BZP-TSC's in this study, have proven to be a special class of ligands with many biological properties. The ligands themselves are often potent ribonucleotide reductase inhibitors (such as Triapine), but have very little inhibitory effect against topoII $\alpha$. However, we show in this study that the copper(II) complexes of those ligands with the formula [Cu(BZP-TSC)Cl] are potent topoisomerase II $\alpha$ inhibitors, just as has been shown to be the case for the analogous copper(II) complexes of the formylpyridine thiosemicarbazones, [Cu(FP-TSC)Cl], acetylpyridine thiosemicarbazones, [Cu(APY-TSC)Cl], and acetylpyrazine thiosemicarbazones, [Cu(APZ-TSC)Cl]. The alkyl and aryl 


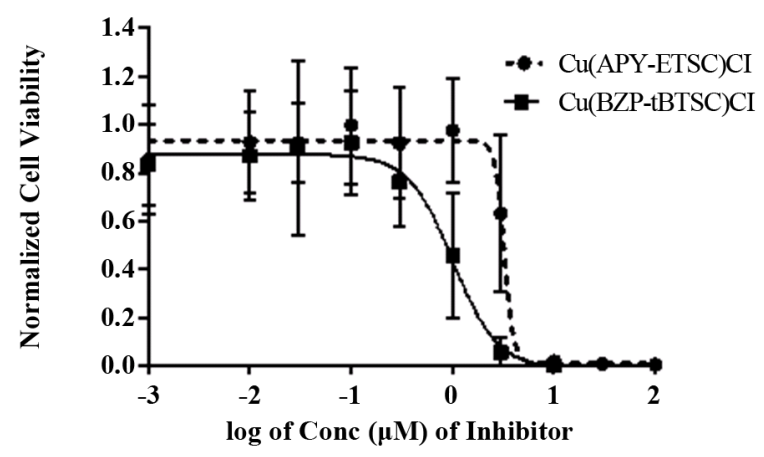

Figure 4. Viability curve for MDA-MB-231 cells with compounds [Cu(APY-ETSC)Cl] (solid circles) and [Cu(BZP-tBTSC)Cl] (solid squares). The calculated EC50 for [Cu(APY-ETSC)Cl] and $[\mathrm{Cu}$ (BZP-tBTSC)Cl] is $3.33 \mu \mathrm{M}$ and $1.01 \mu \mathrm{M}$ respectively.

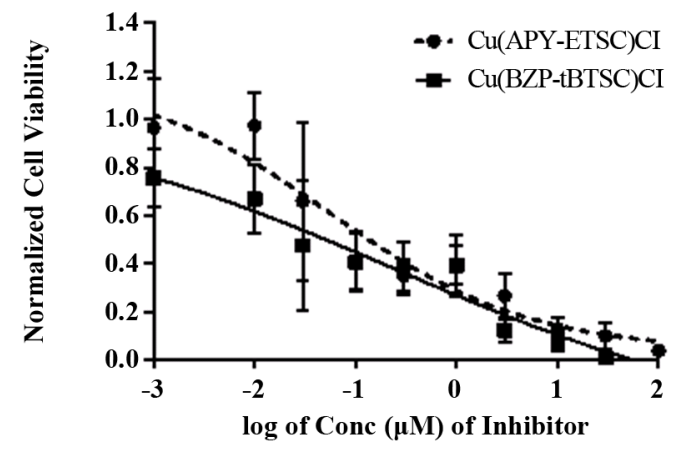

Figure 5. Viability curve for MCF7 cells with compounds [Cu(APYETSC)Cl] (solid circles) and [Cu(BZP-tBTSC)Cl] (solid squares). The calculated EC50 for [Cu(APY-ETSC)Cl] and [Cu(BZP-tBTSC) $\mathrm{Cl}]$ is $0.0558 \mu \mathrm{M}$ and $0.248 \mu \mathrm{M}$ respectively.

substituents on the end of the thiosemicarbazone ligand, such as methyl, ethyl, tert-butyl, phenyl, etc., seem to have no real effect on the efficacy of the copper(II) complexes to inhibit the action of human topoII $\alpha$ as we have determined in this study.

If the substituents on the thiosemicarbazone seem to have no real effect, and the imine portion of the copper complex can be either a formyl, acetyl, or even a benzoyl group, as we have shown here, then the question of the mechanism of action of the copper complexes to inhibit topoII $\alpha$ now seems to focus on the square-planar geometry of these complexes, which is rare for copper (II), and the nature of the $\mathrm{Cu}-\mathrm{Cl}$ bond. Studies in the future may address the question of whether or not the [Cu(BZP-TSC)Cl] complexes react with the topoII $\alpha$ enzyme to become five or six coordinate, and whether or not the $\mathrm{Cu}-\mathrm{Cl}$ bond is involved in this process.

In summary, our results demonstrate that $\mathrm{Cu}(\mathrm{II}) \mathrm{BZP}-\mathrm{TSC}$ complexes are better topoII $\alpha$ inhibitors compared with the BZP-TSC ligands and that the [Cu(BZP-tBTSC)Cl] complex inhibits topoII $\alpha$ in a dose-dependent way. Additionally, the [Cu(BZP-tBTSC)Cl] complex also appears to be more effective at killing MDA-MB-231 and MCF7 breast cancer cell lines than does [Cu(APY-ETSC)Cl].

\section{Acknowledgements}

J.D.C. thanks the TTU Chemistry Department for a Student Research Grant, and M.T.S. thanks the TTU URECA! Program for a research mini-grant.

\section{References}

[1] Beraldo, H. and Gambino, D. (2004) The Wide Pharmacological Versatility of Semicarbazones, Thiosemicarbazones and Their Metal Complexes. Mini-Reviews in Medicinal Chemistry, 4, 31-39. 
http://dx.doi.org/10.2174/1389557043487484

[2] Brockman, R., Sidwell, R., Arnett, G. and Shaddix, S. (1970) Heterocyclic Thiosemicarbazones: Correlation between Structure, Inhibition of Ribonucleotide Reductase, and Inhibition of DNA Viruses. Proceedings of the Society for Experimental Biology and Medicine, 133, 609-614. http://dx.doi.org/10.3181/00379727-133-34528

[3] Bavin, E.M., Rees, R.J.W., Robson, J.M., Seiler, M., Seymour, D.E. and Suddaby, D. (1950) The Tuberculostatic Activity of Some Thiosemicarbazones. Journal of Pharmacy and Pharmacology, 2, 764-772. http://dx.doi.org/10.1111/j.2042-7158.1951.tb13043.x

[4] Koch, O. and Stuttgen, G. (1950) Clinical and Experimental Studies on the Effects of Thiosemicarbazones. NaunynSchmiedebergs Archiv für experimentelle Pathologie und Pharmakologie, 210, 409-423. http://dx.doi.org/10.1007/BF00246392

[5] Kune, G.A. (1964) To-Day’s Drugs: Methisazone. BMJ, 2, 621. http://dx.doi.org/10.1136/bmj.2.5409.621

[6] Padhye, S. and Kauffman, G.B. (1985) Transition Metal Complexes of Semicarbazones and Thiosemicarbazones. Coordination Chemistry Reviews, 63, 127-160. http://dx.doi.org/10.1016/0010-8545(85)80022-9

[7] Casas, J.S., Garcia-Tasende, M.S. and Sordo, J. (2000) Main Group Metal Complexes of Semicarbazones and Thiosemicarbazones. A Structural Review. Co- ordination Chemistry Reviews, 209, 197-261.

[8] Yu, Y., Kalinowski, D.S., Kovacevic, Z., Siafakas, A.R., Jansson, P.J., Stefani, C., Lovejoy, D.B., Sharpe, P.C., Bernhardt, P.V. and Richardson, D.R. (2009) Thiosemicarbazones from the Old to New: Iron Chelators That Are More than Just Ribonucleotide Reductase Inhibitors. Journal of Medicinal Chemistry, 52, 5271-5294. http://dx.doi.org/10.1021/jm900552r

[9] Matesanz, A. and Souza, P. (2009). $\alpha$-N-Heterocyclic Thiosemicarbazone Derivatives as Potential Antitumor Agents: A Structure-Activity Relationship. Mini-Reviews in Medicinal Chemistry, 9, 1389-1396. http://dx.doi.org/10.2174/138955709789957422

[10] Moorthy, N., Cerquiera, N., Ramos, M. and Fernandez, P. (2013) Development of Ribonucleotide Reductase Inhibitor: A Review on Structure Activity Relationships. Mini-Reviews in Medicinal Chemistry, 13, 1-11. http://dx.doi.org/10.2174/13895575113136660090

[11] Finch, R.A., Liu, M., Grill, S.P., Rose, W.C., Loomis, R., Vasquez, K.M., Cheng, Y.C. and Sartorelli, A.C. (2000) Triapine (3-Aminopyridine-2-carboxaldehyde-thiosemicarbazone): A Potent Inhibitor of Ribonucleotide Reductase Activity with Broad Spectrum Antitumor Activity. Biochemical Pharmacology, 59, 983-991. http://dx.doi.org/10.1016/S0006-2952(99)00419-0

[12] Knox, J.J., Hotte, S.J., Kollmannsberger, C., Winquist, E., Fisher, B. and Eisenhauer, E.A. (2007) Phase II Study of Triapine ${ }^{\circledR}$ in Patients with Metastatic Renal Cell Carcinoma: A Trial of the National Cancer Institute of Canada Clinical Trials Group (NCIC IND. 161). Investigational New Drugs, 25, 471-477. http://dx.doi.org/10.1007/s10637-007-9044-9

[13] Ma, B., Goh, B.C., Tan, E.H., Lam, K.C., Soo, R., Leong, S.S., Wang, L.Z., Mo, F., Chan, A.T.C., Zee, B. and Mok, T. (2008) A Multicenter Phase II Trial of 3-Aminopyridine-2-carboxaldehyde Thiosemicarbazone (3-AP, Triapine ${ }^{\circledR}$ ) and Gemcitabine in Advanced Non-Small-Cell Lung Cancer with Pharmacokinetic Evaluation Using Peripheral Blood Mononuclear Cells. Investigational New Drugs, 26, 169-173. http://dx.doi.org/10.1007/s10637-007-9085-0

[14] Easmon, J., Heinisch, G., Holzer, W. and Rosenwirth, B. (1992) Pyridazines. 63. Novel Thiosemicarbazones Derived from Formyl- and Acyldiazines: Synthesis, Effects on Cell Proliferation, and Synergism with Antiviral Agents. Journal of Medicinal Chemistry, 35, 3288-3296. http://dx.doi.org/10.1021/jm00095a027

[15] West, D.X., Ives, J.S., Krejci, J., Salberg, M.M., Zumbahlen, T.L., Bain, G.A., Liberta, A.E., Valdes-Martinez, J., Hernandez-Ortiz, S. and Toscano, R.A. (1995) Copper (II) Complexes of 2-Benzoylpyridine ${ }^{4}$ N-Substituted Thiosemicarbazones. Polyhedron, 14, 2189-2200. http://dx.doi.org/10.1016/0277-5387(95)00010-P

[16] Easmon, J., Puerstinger, G., Heinisch, G., Roth, T., Fiebig, H.H., Holzer, W., Jaeger, W., Jenny, M. and Hofmann, J. (2001) Synthesis, Cytotoxicity, and Antitumor Activity of Copper(II) and Iron(II) Complexes of ${ }^{4} \mathrm{~N}$-Azabicyclo[3.2.2]nonane Thiosemicarbazones Derived from Acyl Diazines. Journal of Medicinal Chemistry, 44, 2164-2171. http://dx.doi.org/10.1021/jm000979z

[17] Shao, J., Zhou, B., Di Bilio, A.J., Zhu, L., Wang, T., Qi, C., Shih, J. and Yen, Y. (2006) A Ferrous-Triapine Complex Mediates Formation of Reactive Oxygen Species That Inactivate Human Ribonucleotide Reductase. Molecular Cancer Therapeutics, 5, 586-592. http://dx.doi.org/10.1158/1535-7163.MCT-05-0384

[18] Kalinowski, D.S. and Richardson, D.R. (2007) Future of Toxicology-Iron Chelators and Differing Modes of Action and Toxicity: The Changing Face of Iron Chelation Therapy. Chemical Research in Toxicology, 20, 715-720. http://dx.doi.org/10.1021/tx700039c

[19] Jansson, P.J., Sharpe, P.C., Bernhardt, P.V. and Richardson, D.R. (2010) Novel Thiosemicarbazones of the ApT and DpT Series and Their Copper Complexes: Identification of Pronounced Redox Activity and Characterization of Their 
Antitumor Activity. Journal of Medicinal Chemistry, 53, 5759-5769. http://dx.doi.org/10.1021/jm100561b

[20] Zeglis, B.M., Divilov, V. and Lewis, J.S. (2011) Role of Metalation in the Topoisomerase II $\alpha$ Inhibition and Antiproliferation Activity of a Series of $\alpha$-Heterocyclic- $\mathrm{N}^{4}$-Substituted Thiosemicarbazones and Their Cu(II) Complexes. Journal of Medicinal Chemistry, 54, 2391-2398. http://dx.doi.org/10.1021/jm101532u

[21] Yalowich, J.C., Wu, X., Zhang, R., Kanagasabai, R., Hornbaker, M. and Hasinoff, B.B. (2012) The Anticancer Thiosemicarbazones Dp44mT and Triapine Lack Inhibitory Effects as Catalytic Inhibitors or Poisons of DNA Topoisomerase II $\alpha$. Biochemical Pharmacology, 84, 52-58. http://dx.doi.org/10.1016/j.bcp.2012.03.021

[22] Deweese, J.E. and Osheroff, N. (2008) The DNA Cleavage Reaction of Topoisomerase II: Wolf in Sheep's Clothing. Nucleic Acids Research, 37, 738-748. http://dx.doi.org/10.1093/nar/gkn937

[23] Felix, C.A. (1998) Secondary Leukemias Induced by Topoisomerase-Targeted Drugs. Biochimica et Biophysica Acta (BBA)-Gene Structure and Expression, 1400, 233-255. http://dx.doi.org/10.1016/S0167-4781(98)00139-0

[24] Stefani, C., Jansson, P.J., Gutierrez, E., Bernhardt, P.V., Richardson, D.R. and Kalinowski, D.S. (2012) Alkyl Substituted 2'-Benzoylpyridine Thiosemicarbazone Chelators with Potent and Selective Anti-Neoplastic Activity: Novel Ligands That Limit Methemoglobin Formation. Journal of Medicinal Chemistry, 56, 357-370. http://dx.doi.org/10.1021/jm301691s

[25] Kalinowski, D.S., Yu, Y., Sharpe, P.C., Islam, M., Liao, Y.-T., Lovejoy, D.B., Kumar, N., Bernhardt, P.V. and Richardson, D.R. (2007) Design, Synthesis, and Characterization of Novel Iron Chelators: Structure-Activity Relationships of the 2-Benzoylpyridine Thiosemicarbazone Series and Their 3-Nitrobenzoyl Analogues as Potent Antitumor Agents. Journal of Medicinal Chemistry, 50, 3716-3729. http://dx.doi.org/10.1021/jm070445z

[26] Yu, Y., Rahmanto, Y.S. and Richardson, D.R. (2012) Bp44mT: An Orally Active Iron Chelator of the Thiosemicarbazone Class with Potent Anti-Tumour Efficacy. British Journal of Pharmacology, 165, 148-166. http://dx.doi.org/10.1111/j.1476-5381.2011.01526.x

[27] Lukmantara, A.Y., Kalinowski, D.S., Kumar, N. and Richardson, D.R. (2013) Structure-Activity Studies of 4-PhenylSubstituted 2'-Benzoylpyridine Thiosemicarbazones with Potent and Selective Anti-Tumour Activity. Organic \& Biomolecular Chemistry, 11, 6414-6425. http://dx.doi.org/10.1039/c3ob41109e

[28] Pingaew, R., Prachayasittikul, S. and Ruchirawat, S. (2010) Synthesis, Cytotoxic and Antimalarial Activities of Benzoyl Thiosemicarbazone Analogs of Isoquinoline and Related Compounds. Molecules, 15, 988-996. http://dx.doi.org/10.3390/molecules15020988

[29] De, K. and Guha, A.K. (1990) 2-Benzoylpyridine Thiosemicarbazone and Its Complexes. Indian Journal of Chemistry, 29A, 605-607.

[30] West, D.G., Stark, A.M., Bain, G.A. and Liberta, A.E. (1996) Copper(II) Complexes of 2-Formyl-, 6-Methyl-2-formyland 2-Benzoylpyridine N(4)-(2-methylpyridinyl)-, N(4)-(2-ethylpyridinyl)- and N(4)-methyl(2-ethylpyridinyl) Thiosemicarbazones. Transition Metal Chemistry, 21, 289-295. http://dx.doi.org/10.1007/BF00139020

[31] Sreekanth, A. and Prathapachandra Karup, M.R. (2003) Structural and Spectral Studies on Four Coordinate Copper(II) Complexes of 2-Benzoylpyridine N(4),N(4)-(butane-1,4-diyl)thiosemicarbazone. Polyhedron, 22, 3321-3332. http://dx.doi.org/10.1016/j.poly.2003.07.011

[32] Joseph, M., Kuriakose, M., Prathapachandra Karup, M.R., Suresh, E., Kishore, A. and Bhat, S.G. (2006) Structural, Antimicrobial and Spectral Studies of Copper(II) Complexes of 2-Benzoylpyridine N(4)-phenyl Thiosemicarbazone. Polyhedron, 25, 61-70. http://dx.doi.org/10.1016/j.poly.2005.07.006

[33] Mendes, I.C., Moreira, J.P., Speziali, N.L., Mangrich, A.S., Takahashi, J.A. and Beraldo, H. (2006) N(4)-tolyl-2-benzoylpyridine Thiosemicarbazones and Their Copper(II) Complexes with Significant Antifungal Activity. Crystal Structure of N(4)-para-tolyl-2-benzoylpyridine Thiosemicarbazone. Journal of the Brazilian Chemical Society, 17, 1571-1577. http://dx.doi.org/10.1590/S0103-50532006000800013

[34] West, D.X., Ives, J.S., Krejci, J., Salberg, M., Zumbahlen, T.L., Bain, G., Liberta, A., Martinez, J.V., Ortiz, S.H. and Toscano, R. (1995) Copper(II) Complexes of 2-Benzoylpyridine ${ }^{4} \mathrm{~N}$-Substituted Thiosemicarbazones. Polyhedron, 14, 2189-2200. http://dx.doi.org/10.1016/0277-5387(95)00010-P

[35] Regal, K.M., Mercer, S.L. and Deweese, J.E. (2014) HU-331 Is a Catalytic Inhibitor of Topoisomerase II $\alpha$. Chemical Research in Toxicology, 24, 2044-2051. http://dx.doi.org/10.1021/tx500245m

[36] Wilson, J.T., Jiang, X., McGill, B.C., Lisic, E.C. and Deweese, J.E. (2016) Examination of the Impact of Copper(II) $\alpha-(N)$-Heterocyclic Thiosemicarbazone Complexes on DNA Topoisomerase II $\alpha$. Chemical Research in Toxicology, Accepted and in Publication. http://dx.doi.org/10.1021/acs.chemrestox.5b00471 